PF 2019 (LXXIII): 385-394

\author{
ELŻBIETA SĘKOWSKA \\ Instytut Polonistyki Stosowanej \\ Wydział Polonistyki \\ Uniwersytet Warszawski \\ ul. Krakowskie Przemieście 26/28, 00-927 Warszawa \\ e-mail: e.j.sekowska@uw.edu.pl
}

\title{
LAUDACJA - WSPÓŁCZESNA ODMIANA MOWY POCHWALNEJ (ROZPOZNANIE WSTĘPNE)
}

SŁOWA KLUCZOWE: amplifikacja, eulogie, powtórzenia, synonimy, zaimki

KEYWORDS: amplification, eulogies, repetitions, synonyms, pronouns

\section{EULOGY - A MODERN VARIATION OF THE SPEECH OF PRAISE (PRELIMINARIES)}

\begin{abstract}
The article contains an analysis of contemporary laudatory speeches devoted to the authors of belles lettres. The reference to the species and linguistic traditions, especially the $19^{\text {th }}$ century, allowed to show the characteristic rhetorical means present in eulogies and the change of the cultural convention in expressing praise.
\end{abstract}

Mowy pochwalne - typ mów okolicznościowych - należące do mów pokazowych (łac. genus demonstrativum) mają swe źródło w retoryce starożytnej greckiej i rzymskiej. Wówczas określono ich strukturę gatunkową i wyrazistą formę stylistyczną zależną od tematu. Wymowa pokazowa dzieliła się na pochwałę (laus) i naganę (vituperatio) (Ziomek 1990, s. 62). Zdaniem Ziomka, w praktyce pochwały były okolicznościowe, towarzyszyły narodzinom, ślubom, pogrzebom, ingresom, nominacjom, dlatego też rodzaj ten był skrępowany obyczajami towarzyszącymi sytuacjom; łatwo dochodziło do degeneracji genus demonstrativum, kiedy to zważanie na okoliczności i osoby prowadziło do wyolbrzymiania pochwały. Pochwała mogła dotyczyć osoby, jak i miejsca czy rzeczy.

Wymowie pokazowej, ze względu na cel mówcy, rolę słuchacza oraz czas i przestrzeń wykonania, przysługiwał styl patetyczny w rozumieniu Arystotelesa: 
(...) páthos znaczy tyle, co „uczucie” (łac. affectus), styl zaś „patetyczny” to z czasem i pośrednio styl wzniosły, u Arystotelesa jeszcze - styl obliczony na poruszenie słuchacza, a więc szczególnie wyszukany, niezwykły, uroczysty (Ziomek 1990, s. 57).

Według Hanny Dziechcińskiej mowy pochwalne należą do szeroko pojmowanego panegiryku; jego właściwością konstytutywną nie była jakaś określona struktura gatunkowa, ale wspólna wielu różnym - z punktu widzenia formalnego - utworom postawa panegiryczna oraz ogół odpowiadających jej środków kompozycyjnych i stylistycznych (Ziomek 1990, s. 544). Komponenty pochwały występowały w różnych gatunkach: mowie, liście, elegii, dedykacji, epigramacie, formach funeralnych, w tym: epicedium i epitafium i innych utworach zaliczanych do literatury okolicznościowej.

Bogatej twórczości panegirycznej w Polsce towarzyszyły refleksje teoretyczne nad istotą pochwały i sposobami jej formułowania ${ }^{1}$.Wykształciły się locicommunes, które służyły do amplifikowania pochwały. Figurami stylistycznymi wykorzystywanymi w utworach były na przykład: hiperbole, antytezy, metafory, epitety $^{2}$. W panegirykach obecne były elementy biografii, wzorce osobowe, idee danego wieku.

Tak zwane laudes, elogia, laudationes, pochwały osób, „znamienitych twórczością naukową lub artystyczno-literacką, pochwały sztuk, nauk, umiejętności, cnót, zawodów, stanów itp.” były specjalną odmianą „wymowy uczonej”, która była praktykowana w życiu akademickim w Polsce już w XV i XVI wieku (Bruchnalski 1918, s. 357-358). Polem, na którym mowy te szczególnie były kultywowane, stały się towarzystwa naukowe, w tym: Królewskie Towarzystwo Przyjaciół Nauk w Warszawie (1800 r.) oraz Towarzystwo Naukowe Krakowskie (1816). Roczniki wymienionych organizacji zawierają teksty wygłoszonych mów. Bruchnalski wymienia przykłady piśmiennictwa tego typu, niekiedy z krótką charakterystyką, np.:

Jan Śniadecki - (...) od r. 1807-1815 sterując tak wielką instytucją jak Uniwersytet Wileński, miał ze stanowiska rektora wiele sposobności do zabierania głosu publicznie, co znalazło wyraz w mowach na cześć Aleksandra I, w pochwałach zmarłych uczonych lub w parenezach, skierowywanych do uczącej się młodzieży. Mowy te, stanowiące jeden z najpiękniejszych pomników owoczesnej oratorii uczonej, pomieszczone są w (...) (Bruchnalski 1918, 363) ${ }^{3}$;

\footnotetext{
1 Ze względu na przedmiot artykułu, którym są laudacje współczesne, przypominam tylko niezbędne fakty historyczne, które są istotne dla dalszej analizy.

2 Przykładowo: bogaty zestaw takich figur zawiera artykuł A. Pihan-Kijasowej (2016) poświęcony językowym i kulturowym komponentom pochwały w XVII-wiecznych kazaniach na pogrzebach kobiet.

3 Dokładniejszą analizę tekstów Jana Śniadeckiego zawiera artykuł M. Smoleń-Wawrzusi$\operatorname{szyn}(2012)$
} 
Paweł Czajkowski (...), prof. literatury polskiej, retoryki i teorii poezji w uniwersytecie krakowskim, jest autorem mowy pogrzebowej i czterech "pochwał życia, talentów i zasług« (...), drukowanych w »Rocznikach Tow. Nauk. Krak.«, a pisanych stylem przesadnym i sztucznym (Bruchnalski 1918, s. 365-366);

Ludwik Osiński (...), profesor literatury porównawczej w uniwersytecie warszawskim, pisał mowy uczone, pochwalne i sądowe (...). Wśród mów jego na podniesienie zasługuje "Mowa na pochwałę Franciszka Dmochowskiego « powiedziana w Towarzystwie Przyj. Nauk. Warsz. 1808 r. (...) (Bruchnalski 1918, s. 367).

Laudacje akademickie są do dzisiaj żywotną odmianą mowy pochwalnej. Ich zastosowanie związane jest z sytuacją jubileuszu uczonego, nadaniem tytułu doktora honoris causa, odnowieniem doktoratu.

Druga połowa XIX wieku, a szczególnie epoka postyczniowa, obfitowała w laudacje jubileuszowe wbrew opinii, że mowy pochwalne nie odgrywały już większej roli w życiu literackim:

Teraz świętowano okrągłe rocznice urodzin lub działalności pisarzy, artystów, aktorów, uczonych, lekarzy, redaktorów czasopism, a także rocznice funkcjonowania spółek handlowych, korporacji i tym podobnych (Malinowska 2004, s. 161).

Autorka na wielu przykładach pokazuje, że sam gatunek, czerpiąc z ustalonych wzorów klasycznych i staropolskich, nie zmienił się zasadniczo, ale zauważalną cechą mów była przesada, która ujawniała się w treści, kompozycji i stylu; o Deotymie mówiono: „kapłanka poezji”, „śpiewaczka”, „strażniczka wiary”, „wysłanniczka Boga” (Malinowska 2004, s. 173).

Dominował gorset konwencji, w który „wtłaczano” jubilata, pozbawiając go cech indywidualnych. Laudacje z II połowy XIX wieku operowały antytezą, amplifikacją, toposem wojownika i rolnika (oracza, siewcy), zestawieniem wątków przeszłości i teraźniejszości; mówcom znane były figury retoryczne i umiejętności oratorskie. Oracje pochwalne docierały do szerszej publiczności dzięki prasie - miały funkcję jednoczenia społeczeństwa w warunkach zaborów, a także aspekt dydaktyczny poprzez wskazywanie osobowości i wartości życia rodzinnego.

Laudacje z drugiej połowy XIX wieku nie doczekały się dotychczas naukowego opracowania, stwierdziła Ewa Malinowska na wstępie cytowanego wyżej artykułu. Według dostępnej mi wiedzy podobny pogląd można przyjąć w odniesieniu do laudacji współczesnych. Mimo że są obecne w życiu akademickim i literackim, nie stały się przedmiotem refleksji teoretycznej: czy to w zakresie przestrzegania konwencji gatunkowej, czy też w zakresie kompozycji i stylu ${ }^{4}$

4 Gwoli ścisłości należy w tym miejscu odnotować artykuł Iwony Loewe z 2006 roku Renesans laudacji. Autorka traktuje współczesne mowy pochwalne jako wydarzenie medialne. Na podstawie skromnego materiału formułuje kilka wniosków odnoszących się do realizacji mowy popisowej. Podkreśla kunszt językowy laudatora w mowach medialnych, co służy implicytnemu 
Takie cechy laudacji, jak sytuacja komunikacyjna, kontekst życiowy gatun$\mathrm{ku}$, czyli wskazanie instytucji, w których dany gatunek funkcjonuje, dominanta stylistyczna, zostaną poddane analizie w niniejszym artykule. Jako przykłady posłużą mowy wygłaszane na cześć laureatów nagród literackich (Nagroda Literacka m.st. Warszawy - 4; Nagroda Nike - 3; Nagroda im. Jerzego Turowicza - 1; Nagroda Literacka im. Jerzego Żuławskiego - 2); Laudacja Julii Hartwig w Alei Gwiazd Literatury; Laudacja Tadeusza Różewicza (nadanie tytułu dr. h. c. Uniwersytetu Jagiellońskiego).

Tematem głównym wymienionych mów jest uzasadnienie przyznania nagrody bądź innego uhonorowania pisarza i jego twórczości. W przypadku nagród literackich jest to skoncentrowanie się na walorach nagrodzonej książki bądź całego dorobku. Przemawianie publiczne musi spełnić warunki określonej sytuacji komunikacyjnej: mówca przemawia w imieniu pewnej społeczności, a ponieważ w tej sytuacji jest to słowo, nad którym dalej się nie dyskutuje, „jego wypowiedzi muszą być od razu celne i przekonywające. Słowem: jeśli nie chcę mówić na próżno przemawiając do WAS, muszę sprawić, by to, co mówię, było lub stało się DLA NAS - dla MNIE z WAMI - warte powiedzenia” (Lalewicz 1975, s. 42).

Mowa przybiera różne formy językowe, które mają wpłynąć na uczucia i postawę słuchacza, i na ten aspekt struktury zwrócę szczególną uwagę. Będzie mi zależało na wskazaniu tych elementów językowych, które zależą od tradycji gatunku, i na tych, które obecnie stanowią elementy powtarzalne, nacechowane stylistycznie, są sfunkcjonalizowane i odpowiadają intencjom mówcy.

Analiza wybranych tekstów pokazuje, że ich funkcja impresywna jest realizowana różnymi typami powtórzeń; moim zdaniem, dominują one we współczesnych laudacjach. Powtórzenie, odmiana figury retorycznej, jest to: „Dwu- bądź wielokrotne wystąpienie określonego elementu jęz.[ykowego] w obrębie wypowiedzi albo jej fragmentu - podstawowa zasada konstrukcji tekstu poetyckiego w opozycji do tekstu prozaicznego. Powtarzane być mogą rozmaite elementy systemu jęz.: akcentowe i iloczasowe (...), fonologiczne (...), leksykalne (...) i gramatyczne (...). Poszczególne typy powtórzeń bywają też w mniejszym natężeniu

manifestowaniu jego obecności, w kontekście akademickim laudatorzy wycofują swoje ujawnianie się, co autorka łączy z toposem skromności istniejącym współcześnie w nauce.

Wnioski te są, moim zdaniem, dyskusyjne. Zbadane przeze mnie laudacje z okazji przyznania nagród literackich potwierdzają w wielu przypadkach kunsztowność języka laudatorów, ale nie służy ona li tylko strategii manifestowania się mówcy: środki językowe są przykładem argumentacji wyboru dokonanego przez jurorów. Perelman (2002) stwierdza: „Nie zrozumiemy ani natury, ani znaczenia mowy popisowej, jeśli przypiszemy jej jako cel sławę mówcy. (...) mowa popisowa ma wzmacniać jednoczenie się wokół pewnych wartości, które chcemy ukazać jako ważniejsze, a które miałyby określać przyszłe działanie” (Perelman 2002, s. 33). Co do współczesnych realizacji mów akademickich myślę, że ich kształt językowy uzależniony jest od zmian stylu naukowego w ciągu XX wieku. Jednak rzecz wymaga badań na większym korpusie tekstów. 
stosowane w tekstach niepoetyckich, lecz świadomie skonstruowanych i wystylizowanych" (ZS 2003, s. 451). W mowach pochwalnych występują następujące typy powtórzeń: anafora, epifora, anadiploza. Ich główną funkcją jest wzmocnienie efektu illokucyjnego wypowiedzi: powtórzenie obejmuje zarówno pojedyncze wyrazy, jak i krótkie zdania bądź zwroty. Wymienione funkcje ilustrują przykłady:

Trze b a słuchać ludzi: (...) Trze b a robić fotografie (...). Trze b a nauczyć się uważności. Bez uważności nie ma mowy o dobrym życiu. Tr z e b a od siebie wymagać. Nad sobą pracować.

[Julia Hartwig w Alei Gwiazd Literatury]

Pomyślałem, że lepiej zwrócić uwagę na zgęszczony sok tej twórczości, jej esencję, jej barwę, ale przede wszystkim znaczenie.

[op.cit.]

(...) pytają poetkę: Jak żyć? Bo kogo mamy dzisiaj pytać jak żyć?

[op.cit.]

(...) wisi pytanie „Więc dlaczego ...? „Dlaczego?”

[Nagroda im. Jerzego Turowicza dla Moniki Sznajderman]

Poezja i doświadczenie Julii Hartwig (...) jest w gruncie rzeczy wielkim Hymnem Życia. Hymnem Miłości. (...) To wielki dzień, wielka chwila i wielka Poetka.

[Julia Hartwig w Alei Gwiazd Literatury]

Jak widać, powtarzane wyrazy wzmacniają znaczenie tych, z którymi sąsiadują: oddają cechy czynności, poezji, postawy poetyckiej. Podobne są funkcje powtórzeń w kolejnych przykładach:

Zaklinając świat $\underline{\mathrm{w}}$ wierszu, $\underline{\mathrm{w}}$ zdaniu, $\underline{\mathrm{w}}$ obrazie, $\underline{\mathrm{w}}$ metaforze poetka zmaga się równocześnie i ze światem, i ze słowem.

[Nagroda Literacka m.st. Warszawy dla Urszuli Kozioł]

Aby wyrazić swój stan, stan swojej duszy, swojego serca i umysłu poetka używa słów najprostszych (...).

[op.cit.]

Pozostajemy pod wielkim wrażeniem jej pracy, jej wysiłku, jej poezji i jednocześnie biografii.

[op.cit.]

Pamięć to nie tylko przywilej, pamięć to także obowiązek, moralny i duchowy obowiązek (...).

[Nagroda Literacka m.st. Warszawy dla Hanny Krall] 
(...) to szkoła myślenia, ale także szkoła stylu, błyskotliwego i niepowtarzalnego stylu (...).

[op.cit.]

W tym tomie jej brak [pociechy - E.S.]. Nie brak natomiast perspektywy metafizycznej.

[Nagroda Literacka m.st. Warszawy dla Jerzego Kronholda]

Powtórzenia stosowane dla podkreślenia treściowego bądź emocjonalnego oddziałują na wolę i umysł słuchaczy; reduplikacja obejmuje nie tylko słowa pełnoznaczne, lecz także zaimki i przyimki; niekiedy nadaje to mowie walor rytmiczności:

Świat ukazywany przez Stasiuka to zatem warstwy cmentarzysk, po minionych wiekach, minionych miejscach, minionych rzeczach, minionych ludziach.

[Nagroda Literacka m.st. Warszawy dla Andrzeja Stasiuka]

W tych pytaniach, w tym krążeniu i błądzeniu po ruinach pamięci i gruzowiskach warszawskiego getta, po zapadłych w ziemię sztetlach, po pustych, choć zasiedlonych domach (...).

[Nagroda im. Jerzego Turowicza dla Moniki Sznajderman]

Tyle ludzi, tyle miejsc, tyle życiowych planów (...).

[op.cit.]

Chce jego [ojca - E.S.] i chce nas chwycić za rękaw i nie puścić.

[op.cit.]

Jako ergon, jako dokonanie jawi się nam $\underline{\mathrm{w}}$ wyglądzie monumentalnym, $\underline{\mathrm{w}}$ dostojnej aurze klasyczności, $\underline{\mathrm{w}}$ sławie (...).

[Laudacja na cześć Tadeusza Różewicza]

(...) stawało się nawet skandalem - skandalem w źródłowych sensach tego słowa $(\ldots)$.

[op.cit.]

Pisarstwo Twoje bowiem (...) pisarstwo to jest wciąż zdumiewającym paradoksem.

[op.cit.]

Nie ma wiodącego narratora, nie ma głównego bohatera, każdy ma swoją wersję.

[Nagroda Nike dla Olgi Tokarczuk]

Kolejnym zabiegiem retoryczno-składniowym jest łączenie ważnego składnika zdania z zaimkiem o funkcji wyłącznie podkreślającej, wskazującej nasilenie 
tego, co oznacza wyraz, któremu towarzyszy; w ten sposób mówca komunikuje stosunek uczuciowy do wypowiedzi ${ }^{5}$ :

Nikt tak jak ona... Nikt też, tak jak ona...

A jej poezja jest dla mnie tak ważna (...);

(...) doświadczenie śmierci jest zarazem szczególne, tak namacalne;

To wielki dzień, wielka chwila i wielka Poetka. I my z nią. Tak szczęśliwie. Tak blisko;

(...) mówi z tak wielką intensywnością, jakby to była sprawa największej wagi, jakby to nie tylko o poezję jako taką jej chodziło.

Wiemy aż nadto dobrze, że taksię działo, że taksię może dziać, że tak się dzieje ...

Ponieważ to właśnie ona [pisarka - E.S.] uosabia ten splot. Dzięki temu splotowi istnieje.

Podobnym zabiegiem wzmacniającym jest amplifikacja: zestawienie obok siebie wyrazów bliskoznacznych, odnoszących się do jednego obiektu, zjawiska: służy to rozwijaniu i uwydatnianiu tematu wypowiedzi:

(...) drobiny, okruchy, fragmenty potrzaskanej rodzinnej historii.

Wschód łuszczy się, obłazi, pęka, rozpada, rdzewieje.

To, które jest wielkie, dzikie, niepoliczalne, zachłanne, niebezpieczne i imponujące.

Bo Bieńczyk wierzy przede wszystkim w literaturę, w słowo, w styl, w pisanie samo w sobie.

W czasach znacznego niechlujstwa, powierzchowności, bylejakości i pospieszności fraza pisarska Marka Bieńczyka przypomina kwintet Schuberta (...).

Cóż, są poeci dla których poezja to drobiazg, błahostka, prestidigitatorska sztuczka, ekwilibrystyczny popis (...).

Zestawiane wyrazy nie są bliskoznacznikami sensu stricto, mają inne nacechowanie stylistyczne, ale analiza składnikowa pozwala odnaleźć w nich wspólny sem, a użyte w kontekście powodują hiperbolizację opisywanego zjawiska. Nie są tylko sztuczką retoryczną, polegającą na bogatym wysłowieniu, ale podkreślają gradację cech opisywanego zjawiska i jego plastyczność 6 .

Klasyczną figurą retoryczną - metaforą - posługiwano się w analizowanych laudacjach oszczędnie; przeważają wśród nich porównania:

5 Tego typu konstrukcje opisała H. Koneczna (1948). Autorka wskazała na przykładach z języka potocznego i z poezji zatracanie właściwego charakteru zaimków na rzecz wyrażania stosunku uczuciowego osoby mówiącej do przedmiotu myśli.

6 Ciągi synonimiczne odgrywają rolę w podkreślaniu ekspresywności wypowiedzi: „Użycie wyrazów o podobnym znaczeniu lub podobnej funkcji tworzy kontekst o charakterze pewnej redundancji, redundancji wszak pozornej, ponieważ konstytuującej istotną - ekspresywną - funkcję komunikatu. Synonimia jest tu bowiem środkiem wzmocnienia, zaakcentowania wymiaru ekspresywnego leksemów składających się na pary bliskoznaczników" (Rejter 2006, s. 82). 
Poezja jak lekkie chybotanie promu, który płynie donikąd lub - (...) w nieznane; [historie rodzinne - E.S.] rwące jak górski potok.

Wreszcie, że trzeba słyszeć muzykę, której wrota otwierają się tak samo jak wrota nieba.

(...) akcja powieści meandruje jak górski strumień.

(...) fraza pisarska Marka Bieńczyka przypomina kwintet Schuberta (...).

Inne ukształtowania metafory są jeszcze rzadsze:

(...) pozwala on [głos - E.S.] na krótki spazm głosowania, a jego ludzka treść trwa w milczeniu lub rodzi złą mowę zapętloną w spiralne zwoje gniewu, rozczarowania lub przeciwnie - bezkrytycznej aprobaty.

(...) śmierć kładzie swoją pieczęć na przedmiotach, na wspomnieniach, na nadziejach.

(...) opowieści utkane $\mathrm{z}$ wielobarwnych nici.

Sami nagradzani twórcy określani są poprzez swoje dokonania; wyrazy wartościujące typu wielki, wybitny występują jednostkowo. W porównaniu z rozbudowaną metaforyką stosowaną w mowach z II połowy XIX wieku widać wyraźną tendencję do zmniejszania stopnia afektacji - tylko raz pojawia się określenie kapłan:

Jeśli świat jest wart tekstu, to Bieńczyk jest kapłanem niezachwianej wiary w słuszność tej tezy. (...) Otóż wszystko może zasługiwać na tekst. Pod jednym warunkiem - że będzie tekstem najwyższej jakości i najpiękniejszej urody.

$\mathrm{Na}$ tle laudacji z okazji przyznawania Nagrody Literackiej m.st. Warszawy i Nagrody Nike odróżniają się stylem mowy na część twórców wyróżnionych Nagrodą im. Jerzego Żuławskiego, która jest przeznaczona dla pisarzy uprawiających literaturę science-fiction. Uzasadnienia przypominają formę krytyki literackiej: odwołują się do wartości warsztatowych, umiejętności konstruowania świata alternatywnego wobec współczesności, co zilustruję wybranym cytatem:

Jej [powieści - E.S.] ograniczony niemal do minimum kostium fantastyczny każe traktować autorski pomysł jako efekt pracy bardziej analitycznej niż kreacyjnej. Niekiedy odnosi się wrażenie, że Inglot powstrzymuje pisarską imaginację, by lepiej oddać mechanizm wypadków, które w powieściowej rzeczywistości doprowadzają literacką Polskę na skraj przepaści (...). (...) pojawia się utwór, który przywołuje nas do porządku. I ma formę właśnie tekstu fantastycznonaukowego. (...) Pisarzowi nie chodziło o czczą zabawę faktami (...), a raczej o pobudzenie do rozważnego, krytycznego osądzania polskiej rzeczywistości tu i teraz. (...) Zrezygnował z fajerwerków fantastycznych na rzecz prowokacji intelektualnej czy nawet politologicznej (...).

(Jacek Inglot, „Polska 2.0”, Nagroda Literacka im. Jerzego Żuławskiego; Toruń 23 września 2017) 
Jak zaznaczono w tytule, analiza mów pochwalnych jest zaledwie badaniem sondażowym. Chodziło mi o wskazanie środków językowych z repertuaru figur retorycznych, które do dzisiaj zachowały żywotność w tej odmianie przemówień; o to, w jaki sposób mówcy oddziałują na uczucia słuchaczy, jakimi środkami osiągana jest wzniosłość stylu. Nawet ta mała próba pokazuje, że najczęściej mówcy posługują się różnymi typami powtórzeń, które służą do wzmacniania efektu illokucyjnego; stosunek uczuciowy wyrażają również zaimki towarzyszące wyrazom, których treść chcemy zaznaczyć; hiperboli służy amplifikacja. Unika się natomiast wyrazów wprost wartościujących. Treści oceniające pozytywnie zawarte są w omówieniach utworu bądź całego dorobku. W porównaniu z laudacjami poświęconymi literatom w II połowie XIX wieku możemy mówić o jakościowej zmianie w podejściu do stosowania określeń bardzo subiektywnych, jawnie oceniających na rzecz wyrażania ocen pośrednio. Wpływa na to typ postawy panegirycznej właściwy danej epoce, jak i wybór środków językowych służących jej wyrażeniu.

Można mówić o zmianie konwencji kulturowej w sposobie wyrażania pochwały. Ważne byłoby prześledzenie ewolucji kategorii podniosłości, chociażby na podstawie danych słownikowych. Aby rzecz szerzej uzasadnić, należałoby dokonać analizy językowo-stylistycznej większej liczby laudacji zebranych według określonych kryteriów sytuacyjnych, np. laudacje akademickie, laudacje z okazji przyznania nagród literackich, laudacje jubileuszowe itp.

\section{Bibliografia}

Bruchnalski, W. (1918). Dzieje literatury pięknej w Polsce. Cz. 2. Kraków: Wydawnictwo Gebethner i Sp.

Dziechcińska, H. (1990). Panegiryk. W: Słownik literatury staropolskiej (544-547). Wrocław-Warszawa-Kraków: Zakład Narodowy im. Ossolińskich.

EJP - Polański, K. (red.) (2003). Encyklopedia językoznawstwa ogólnego. Wrocław: Zakład Narodowy im. Ossolińskich.

Koneczna, H. (1948). O roli uczuciowej tzw. zaimków konwencjonalnych, Poradnik Językowy, 1, 8-14.

Lalewicz, J. (1975). Komunikacja językowa i literatura. Wrocław: Zakład Narodowy im. Ossolińskich.

Loewe, I. (2006). Renesans laudacji. W: M. Kita (red.), Żonglowanie słowami. Językowy potencjał $i$ manifestacje tekstowe (177-186). Katowice: Wyższa Szkoła Zarządzania Marketingowego i Języków Obcych w Katowicach.

Malinowska, E. (2004). W hołdzie „królowej ideału” i „mężom sławy niespożytej”. O laudacjach jubileuszowych z drugiej połowy XIX wieku, Napis, 10, 161-174. 
Perelman, Ch. (2002). Imperium retoryki. Retoryka i argumentacja. Warszawa: Wydawnictwo Naukowe PWN.

Pihan-Kijasowa, A. (2016). Językowe i kulturowe komponenty pochwały w XVII-wiecznych kazaniach na pogrzebach kobiet. W: M. Krajewska, J. Kulwicka-Kamińska, A. Szulc (red.), Święte księgi judaizmu, chrześcijaństwa i islamu w słowiańskim kręgu kulturowym. Prace dedykowane Czestawowi Łapiczowi (119-146). Toruń: Wydawnictwo Naukowe Uniwersytetu Mikołaja Kopernika.

Rejter, A. (2006). Leksyka ekspresywna w historii języka polskiego. Kulturowo-komunikacyjne konteksty potoczności. Katowice: Wydawnictwo Uniwersytetu Śląskiego.

Smoleń-Wawrzusiszyn, M. (2012). Metodologie językoznawcze a tekst retoryczny. Z doświadczeń analiz historycznej prozy użytkowej, Białostockie Archiwum Językowe, 12, 225-238.

Ziomek, J. (1990). Retoryka opisowa. Wrocław: Zakład Narodowy im. Ossolińskich.

\section{Źródła internetowe}

wyborcza.pl $>1,75410,12626889$, Lauda...

wyborcza. pl>1,75410,18966831,nike-2...

www.nagroda-zulawskiego.pl

www.kulturalna.warszawa.pl/Nagroda Literacka m.st. Warszawy

Julia Hartwig w Alei Gwiazd Literatury > remigiusz-grzela.pl

Laudacja Tadeusza Różewicz > hamlet.edu.pl

\section{Streszczenie}

Artykuł zawiera analizę współczesnych mów pochwalnych poświęconych twórcom literatury pięknej. Odniesienie do tradycji gatunkowej i językowej, szczególnie XIX-wiecznej, pozwoliło ukazać charakterystyczne środki retoryczne występujące w laudacjach oraz zmianę konwencji kulturowej w wyrażaniu pochwały. 